RASĀYAN J. Chem.

Vol. 13 | No. 4 |2538-2543| October - December | 2020 ISSN: 0974-1496 | e-ISSN: 0976-0083 | CODEN: RJCABP

\title{
PHYSICO-CHEMICAL AND BIOLOGICAL STUDIES ON THE COORDINATION COMPOUNDS OF N-(2- CARBAMOYLFURANYL)-C-(3'-CARBOXY-2'- HYDROXYPHENYL) AZETIDIN-2-ONE
}

\author{
Praveen Kr. Gupta ${ }^{1}$, Dinesh Kumar ${ }^{2}$, Amit Kumar ${ }^{3, *}$ and Durga Dass ${ }^{4}$ \\ ${ }^{1}$ Department of Chemistry, Maharishi Markandeshwar (Deemed to be University) \\ Mullana-133207, Ambala, (Haryana) India \\ ${ }^{2}$ Department of Chemistry, National Institute of Technology, \\ Kurukshetra-136118(Haryana) India \\ ${ }^{3}$ Department of Chemistry, Indira Gandhi National College, Ladwa, \\ Kurukshetra-136132, (Haryana) India \\ ${ }^{4}$ Department of Chemistry, Shri Krishan Institute of Engg. \& Tech., \\ Kurukshetra-136118, (Haryana) India \\ *E-mail: amitvash76@gmail.com
}

\begin{abstract}
The Schiff base, N-(2-carbamoylfurany1)-3'-carboxy-2'-hydroxybenzylideneimine reacts with chloro acetyl chloride and forms N-(2-carbamoylfuranyl)-C-(3'-carboxy-2'-hydroxyphenyl) azetidin-2-one, $\mathrm{LH}_{3}(\mathbf{I})$. This is a cyclization reaction and occurs in triethylamine's presence. A MeOH solution of $\mathrm{LH}_{3}$ reacts with $\mathrm{Co}(\mathrm{II})$ and $\mathrm{Ni}$ (II) ions leads to the formation of coordination compounds i.e. $[\mathrm{Co}(\mathrm{LH})(\mathrm{MeOH})]_{2}$ and $[\mathrm{Ni}(\mathrm{LH})]$.

Various characterization tools like elemental analyses, molar conductance, magnetic measurements, Infra red and reflectance spectral studies have been used to characterize these compounds. Both the compounds show nonelectrolytic behavior i.e. molar conductivity lies in the range 1.6 to $5.2 \mathrm{mho} \mathrm{cm}^{2} \mathrm{~mol}^{-1}$ in DMF. The denticity of the ligand is Four i.e. it behaves like a dibasic tetradentate OONO donor ligand in its complexes. $[\mathrm{Co}(\mathrm{LH})(\mathrm{MeOH})]_{2}$ is dimer and the $[\mathrm{Ni}(\mathrm{LH})]$ is monomeric in diphenyl. $[\mathrm{Ni}(\mathrm{LH})]$ shows square-planar while $[\mathrm{Co}(\mathrm{LH})(\mathrm{MeOH})]_{2}$ shows an octahedral structure. $\mathrm{LH}_{3}$ (I) and its complexes while testing with E.Coli. (Gram Negative) and S. Aureus (Grampositive) bacteria show antibacterial activities.

Keywords: Azetidin-2-One, Coordination Compounds, Magnetic Susceptibility, Antibacterial, Complexometric, Magnetically Dilute.
\end{abstract}

(C) RASĀYAN. All rights reserved

\section{INTRODUCTION}

Azetidin-2-ones commonly known as $\beta$-lactams are derivatives of azetidines having a carbonyl group in the second position. Most common antibiotics like cephalosporins, penicillins etc show their activity due to the presence of lactam ring in them.

Azetidin-2-ones have a broad range of biological applications ${ }^{1}$ like antimicrobial, antibacterial, antiinflammatory, anticonvulsant and antitubercular. ${ }^{1-8}$ They are also effective on the central nervous system ${ }^{9}$. Due to its ring strain ${ }^{10}$ the azetidin-2-one, acts as building unit for the synthesis of a large number of organic molecules.

This manuscript includes the syntheses and characterization of N-(2-carbamoylfuranyl)-C-(3'-carboxy-2'hydroxyphenyl)azetidin-2-one, $\mathrm{LH}_{3}$ (I) and its compounds with $\mathrm{Co}(\mathrm{II})$ and $\mathrm{Ni(II)}$ ions.

\section{EXPERIMENTAL}

Furoic acid hydrazide [Aldrich]; nickel (II) acetate, cobalt (II) acetate, methanol, acetone, ethyl acetate, triethylamine, chloroacetyl chloride and dioxane [Ranbaxy] were used for the syntheses. The synthesis of 3-Formylsalicylic acid was done as per the published procedure. ${ }^{11}$ 
RASĀYAN J. Chem.

Vol. 13 | No. 4 |2538-2543| October - December | 2020

\section{Analyses and Physical Measurements}

Before the estimation of metal ions, their organic skeleton must be decomposed. It was done by heating the compound with conc. $\mathrm{HNO}_{3}$ and then the dissolution of residue in the least amount of conc. HCl. Metal ions were estimated as follows:

The estimation of $\mathrm{Co}(\mathrm{II})$ and $\mathrm{Ni}(\mathrm{II})$ contents was done by the complexometric method using EDTA soln. The $\mathrm{C}, \mathrm{H}$ and $\mathrm{N}$ contents of $\mathrm{LH}_{3}$ and its coordination compounds were determined by CHN Eager analyzer model-300.<smiles>O=C(N/N=C/c1cccc(C(=O)O)c1O)c1ccco1</smiles><smiles>C=C/C=N\N=C(/O)c1ccco1</smiles><smiles></smiles>

Schiff Base

[I (keto-form)]<smiles>O=C(O)c1cccc(C2C(Cl)C(=O)N2/N=C(\O)c2ccco2)c1O</smiles>

[I (enol-form)]

Azetidin-2-one, $\mathrm{LH}_{3}(\mathrm{I})$

Schiff base $\underset{\text { dioxane }}{\stackrel{\text { CAC, TEA }}{\longrightarrow}} \longrightarrow \mathrm{LH}_{3}(\mathrm{I})$

[CAC: Chloroacetyl chloride; TEA: Triethylamine]

Scheme-I: Preparation of N-(2-carbamoylfuranyl)-C-(3'-carboxy-2'-hydroxyphenyl) azetidin-2-one (I)

$$
\begin{gathered}
\mathrm{LH}_{3}+\mathrm{Co}(\mathrm{OAc})_{2} \cdot 4 \mathrm{H}_{2} \mathrm{O} \underset{\text { Reflux }}{\stackrel{\mathrm{MeOH}}{\longrightarrow}}[\mathrm{Co}(\mathrm{LH})(\mathrm{MeOH})]_{2}+2 \mathrm{CH}_{3} \mathrm{COOH}+4 \mathrm{H}_{2} \mathrm{O} \\
\mathrm{LH}_{3}+\mathrm{Ni}(\mathrm{OAc})_{2} \cdot 4 \mathrm{H}_{2} \mathrm{O} \underset{\text { Reflux }}{\stackrel{\text { MeOH }}{\longrightarrow}}[\mathrm{Ni}(\mathrm{LH})]+2 \mathrm{CH}_{3} \mathrm{COOH}+4 \mathrm{H}_{2} \mathrm{O}
\end{gathered}
$$

Scheme-II: Preparation of coordination compounds of N-(2-carbamoylfuranyl)-C-(3'-carboxy-2'-hydroxyphenyl) azetidin-2-one (I)

The $\mathrm{S}$ and $\mathrm{Cl}$ contents were estimated gravimetrically. Rast method was used for the determination of the molecular weight ${ }^{12}$. The IR and reflectance spectra were recorded by Beckman-20 spectrophotometer. The magnetic susceptibility measurements were carried out as per the mentioned procedures. ${ }^{13}$

Synthesis of the Schiff base [N-(2-carbamoylf u ran yl)-3'-carboxy-2'-hydroxybenzylideneimine] The titled compound was synthesized by following the published procedure. ${ }^{14}$

Synthesis of N-(2-carbamoylf u ra nyl)-C-(3'-carboxy-2'-hydroxyphenyl)azetidin-2-one (I)

A dioxane solution $(50 \mathrm{~mL})$ of the Schiff base $(2.74 \mathrm{~g}, 10 \mathrm{mmol})$ was stirred with the dropwise addition of chloroacetyl chloride $(2.26 \mathrm{~g}, 20 \mathrm{mmol})$ in presence of triethylamine $(3.03 \mathrm{~g}, 30 \mathrm{mmol})$. Volume of the 
RASĀYAN J. Chem.

Vol. 13 | No. 4 |2538-2543| October - December | 2020

filtrate was reduced to half. Triethylamine hydrochloride formed was filtered off and the the solution was kept aside for $24 \mathrm{~h}$ and the solid product formed was filtered, washed with dioxane and recrystallized from $\mathrm{CHCl}_{3}$. The compound was dried in vacuo. Yield $=26 \%$. Anal: $\left(\mathbf{I}, \mathrm{C}_{15} \mathrm{H}_{11} \mathrm{~N}_{2} \mathrm{O}_{6} \mathrm{Cl}\right)$ (obsd: $\mathrm{C}, 51.03 \%$; $\mathrm{H}$, $3.17 \%$; N, 7.84\%; Cl, 10.28\%. calc.: C, 51.36\%; H, 3.14\%; N, 7.99\%; Cl, 10.13\%); IR bands (KBr): $2895 \mathrm{~cm}^{-1}[v(\mathrm{O}-\mathrm{H})($ intramolecular $\quad$ H-bonding $)], 1745 \mathrm{~cm}^{-1}[v(\mathrm{C}==\mathrm{O})(\beta$-lactam $)], 1670 \mathrm{~cm}^{-1}$ $[v(\mathrm{C}==\mathrm{O})($ amide $)], 1540 \mathrm{~cm}^{-1}[v(\mathrm{C}-\mathrm{O}) \phi], 1414 \mathrm{~cm}^{-1}[v(\mathrm{C}-\mathrm{N})(\beta-$ lactam $)], 1080 \mathrm{~cm}^{-1}[v(\mathrm{C}-\mathrm{O}-$ C)(furan) $]$ and $750 \mathrm{~cm}^{-1}[\mathrm{v}(\mathrm{C}-\mathrm{Cl})(\beta$-lactam $)]$.

\section{Syntheses of Coordination Compounds of I}

A methanolic solution $(30-50 \mathrm{~mL})$ of the metal salt $(10 \mathrm{mmol})$ was added to a methanolic solution $(50 \mathrm{~mL})$ of $\mathbf{I}(3.50 \mathrm{~g}, 10 \mathrm{mmol})$ and the mixture was then refluxed for $3-4 \mathrm{~h}$. The solid products formed were filtered, washed with methanol and were then dried as mentioned above. Yield $=45-65 \%$.

\section{RESULTS AND DISCUSSION}

$\mathrm{N}$-(2-Carbamoylfuranyl)-C-(3'-carboxy-2'-hydroxyphenyl)azetidin-2-one, $\mathrm{LH}_{3}(\mathbf{I})$ was synthesized by the reaction of chloroacetyl chloride on the Schiff base, N-(2-carbamoylfuranyl)-3'-carboxy-2'hydroxybenzylideneimine. The reaction of $\mathbf{I}$ with metal salts in 1:1 molar ratio in methanol produces the coordination compounds of the types, $[\mathrm{Co}(\mathrm{LH})(\mathrm{MeOH})]_{2}$ and $[\mathrm{Ni}(\mathrm{LH})]$. The coordination compounds are insoluble in $\mathrm{H}_{2} \mathrm{O}, \mathrm{MeOH}$ and $\mathrm{EtOH}$. They are partially soluble in $\mathrm{CHCl}_{3}, \mathrm{Me}_{2} \mathrm{CO}, \mathrm{C}_{6} \mathrm{H}_{6}$ and completely soluble in DMSO and DMF. They are non-electrolytes $\left(\Lambda_{\mathrm{M}}=1.6-5.2 \mathrm{mho} \mathrm{cm}^{2} \mathrm{~mol}^{-1}\right)$ in DMF. The analytical data of $\mathbf{I}$ and its coordination compounds are given in Table-1.

Table-1: Analytical, Molar Conductance $\left(\Lambda_{\mathrm{M}}\right)$ and Molecular Weight Data of I and its Coordination Compounds

\begin{tabular}{|c|c|c|c|c|c|c|c|c|}
\hline \multirow[t]{2}{*}{ Compound } & \multirow[t]{2}{*}{ Mol. Formula } & \multirow{2}{*}{$\begin{array}{c}\Lambda_{\mathrm{M}} \\
\left(\mathrm{mho} \mathrm{cm}^{2}\right. \\
\left.\mathrm{mol}^{-1}\right)\end{array}$} & \multirow{2}{*}{$\begin{array}{l}\text { Mol. Wt } \\
\text { Obsd. } \\
\text { (Cal.) }\end{array}$} & \multicolumn{5}{|c|}{ Obsd(Cal) $\%$} \\
\hline & & & & M & $\mathrm{C}$ & $\mathrm{H}$ & $\mathrm{N}$ & $\mathrm{Cl}$ \\
\hline $\mathrm{LH}_{3}(\mathrm{I})$ & $\mathrm{C}_{15} \mathrm{H}_{11} \mathrm{~N}_{2} \mathrm{O}_{6} \mathrm{Cl}$ & & $\begin{array}{l}349.0^{a} \\
(350.5)\end{array}$ & - & $\begin{array}{c}51.03 \\
(51.36)\end{array}$ & $\begin{array}{c}3.17 \\
(3.14)\end{array}$ & $\begin{array}{c}7.84 \\
(7.99)\end{array}$ & $\begin{array}{c}10.28 \\
(10.13)\end{array}$ \\
\hline $\begin{array}{c}{[\mathrm{Co}(\mathrm{LH})(\mathrm{MeO}} \\
\mathrm{H})]_{2}\end{array}$ & $\mathrm{Co}_{2} \mathrm{C}_{32} \mathrm{H}_{26} \mathrm{~N}_{4} \mathrm{O}_{14} \mathrm{Cl}_{2}$ & 1.6 & $\begin{array}{l}855.3^{\mathrm{b}} \\
(878.8)\end{array}$ & $\begin{array}{c}13.07 \\
(13.40)\end{array}$ & $\begin{array}{c}43.52 \\
(43.69)\end{array}$ & $\begin{array}{c}2.88 \\
(2.96)\end{array}$ & $\begin{array}{c}6.32 \\
(6.37)\end{array}$ & $\begin{array}{c}8.16 \\
(8.08)\end{array}$ \\
\hline$[\mathrm{Ni}(\mathrm{LH})]$ & $\mathrm{NiC}_{15} \mathrm{H}_{9} \mathrm{~N}_{2} \mathrm{O}_{6} \mathrm{Cl}$ & 5.2 & $\begin{array}{l}436.6^{b} \\
(407.2)\end{array}$ & $\begin{array}{l}14.05 \\
(14.42)\end{array}$ & $\begin{array}{c}44.16 \\
(44.20)\end{array}$ & $\begin{array}{c}2.17 \\
(2.21)\end{array}$ & $\begin{array}{c}6.83 \\
(6.88)\end{array}$ & $\begin{array}{c}8.92 \\
(8.72)\end{array}$ \\
\hline
\end{tabular}

Abbreviations: ${ }^{a}$ Mass Spectral Data, ${ }^{b}$ Rast Method Data

\section{Infrared Spectral Studies}

The infrared spectra of the $\mathrm{LH}_{3}(\mathbf{I})$ and its coordination compounds were mentioned in Table- 2 . The $v(\mathrm{C}-$ $\mathrm{N})\left(\beta\right.$-lactam) stretch ${ }^{15}$ in I at $1414 \mathrm{~cm}^{-1}$ confirms the conversion of Schiff base to azetidinone. A (C$\mathrm{Cl})\left(\beta\right.$-lactam) stretch ${ }^{16}$ at $750 \mathrm{~cm}^{-1}$ further supports the same. A strong band due to intramolecular $\mathrm{H}$ bonded $\mathrm{OH}$ group of phenolic and/or carboxylic acid moieties ${ }^{17}$ at $2895 \mathrm{~cm}^{-1}$ in $\mathbf{I}$ get disappears in its coordination compounds showing the deprotonation of the $\mathrm{OH}$ groups followed by the involvement of phenolic and carboxylic acid $\mathrm{O}$ atoms towards coordination.

The presence of a broadband between $3350-3450 \mathrm{~cm}^{-1}$ due to the $v(\mathrm{O}-\mathrm{H})(\mathrm{MeOH})$ stretch and the decrease of the $v(\mathrm{C}-\mathrm{O})(\mathrm{MeOH})$ stretch from $1034 \mathrm{~cm}^{-1}$ to lower energy by $58 \mathrm{~cm}^{-1}$ in the coordination compounds of $\mathrm{Co}(\mathrm{II})$ ions with $\mathrm{I}$ indicate the involvement of the $\mathrm{O}$ atom of $\mathrm{MeOH}$ towards coordination ${ }^{18}$. The presence of $v(\mathrm{C}==\mathrm{O})$ (amide) stretch at $1670 \mathrm{~cm}^{-1}$ in I shows its occurrence in keto form. [Ni( $\left.\left.\mathrm{LH}\right)\right]$ shows the same band which indicates the non-involvement of this keto $\mathrm{O}$ atom towards coordination.

In $[\mathrm{Co}(\mathrm{LH})(\mathrm{MeOH})]_{2}$ the absence of $v(\mathrm{C}==\mathrm{O})\left(\right.$ amide) stretch and presence of a band at $1255 \mathrm{~cm}^{-1}$ due to $v \mathrm{C}(\mathrm{OH})$ (enolic) stretch indicating the conversion of $-\mathrm{C}(\mathrm{O}) \mathrm{NH}-$ moiety (keto-form) into $-\mathrm{C}(\mathrm{OH})==\mathrm{N}-$ moiety (enol-form). It shows the coordination through the enolic $\mathrm{O}$ atom. A decrease of $29-44 \mathrm{~cm}^{-1}$ in $v(\mathrm{C}-$ $-\mathrm{N})\left(\beta\right.$-lactam) stretch of $\mathbf{I}$ in the complexes shows the involvement of its $\mathrm{N}$ atom towards coordination ${ }^{19}$. The appearance of $v(\mathrm{C}==\mathrm{O})(\beta$-lactam $) \mathrm{stretch}^{20}$ at $1745 \mathrm{~cm}^{-1}$ in the coordination compounds i.e. at the same frequency as in $\mathbf{I}$ indicates the non-involvement of $\mathrm{O}$ atom of $\beta$-lactam moiety towards coordination. The 
RASĀYAN J. Chem.

Vol. 13 | No. 4 |2538-2543| October - December | 2020

carboxylate moiety coordinates in a monodentate manner ${ }^{21}$ in the coordination compounds as indicated by the energy difference of 205-206 $\mathrm{cm}^{-1}$ in the $v_{\text {as }}(\mathrm{COO})$ and $v_{\mathrm{s}}(\mathrm{COO})$ stretches which appears between 1535 $1548 \mathrm{~cm}^{-1}$ and $1330-1342 \mathrm{~cm}^{-1}$ respectively. $[\mathrm{Ni}(\mathrm{LH})]$ and $[\mathrm{Co}(\mathrm{LH})(\mathrm{MeOH})]_{2}$ show a higher shift by 10 and $20 \mathrm{~cm}^{-1}$ respectively in the $v(\mathrm{C}-\mathrm{O})$ (phenolic) stretch ${ }^{22}$ supporting the involvement of phenolic $\mathrm{O}$ atom towards coordination. The appearance of $v(C-\mathrm{Cl})(\beta$-lactam $)$ stretch $^{16}$ at $750 \mathrm{~cm}^{-1}$ in the coordination compounds i.e. at the same frequency as in $\mathbf{I}$ indicates its non-involvement towards coordination. A decrease of $v(\mathrm{C}-\mathrm{O}-\mathrm{C})\left(\right.$ furan moiety) ${ }^{23}$ stretch of the ligand at $1080 \mathrm{~cm}^{-1}$ by $45 \mathrm{~cm}^{-1}$ in $[\mathrm{Ni}(\mathrm{LH})]$ shows its involvement in coordination, while it remains unchanged in $[\mathrm{Co}(\mathrm{LH})(\mathrm{MeOH})]_{2}$. Some non-ligand bands in these coordination compounds are assigned to the $v(\mathrm{M}-\mathrm{O})\left(545-560 \mathrm{~cm}^{-1}\right)$ and the $v(\mathrm{M}-\mathrm{N})\left(425-440 \mathrm{~cm}^{-}\right.$ $\left.{ }^{1}\right)$ and these bands are in the expected order of increasing energy: $v(\mathrm{M}-\mathrm{N})<v(\mathrm{M}-\mathrm{O}) .{ }^{24}$

\section{Reflectance Spectral Studies}

$[\mathrm{Co}(\mathrm{LH})(\mathrm{MeOH})]_{2}$ shows three bands at $8930,13200,20200 \mathrm{~cm}^{-1}$ due to ${ }^{4} T_{1 \mathrm{~g}}(F) \rightarrow{ }^{4} T_{2 \mathrm{~g}}\left(v_{1}\right),{ }^{4} T_{1 \mathrm{~g}}(F) \rightarrow$ ${ }^{4} A_{2 \mathrm{~g}}\left(v_{2}\right)$ and ${ }^{4} T_{\mathrm{gg}}(F) \rightarrow{ }^{4} T_{\mathrm{gg}}\left(v_{3}\right)$ transitions, respectively, indicating its octahedral geometry ${ }^{25}$. The various spectral parameters are: $v_{3} / v_{1}$ value $=2.26, D q=1011 \mathrm{~cm}^{-1}, B^{\prime}=830 \mathrm{~cm}^{-1}, \beta=B^{\prime} / B=0.85, \beta^{0}=15 \%$ and CFSE $=-96.6 \mathrm{~kJ} \mathrm{~mol}^{-1}$. The ligand is strong field ${ }^{26}$ in nature and its coordination compounds shows covalence as indicated by the reduction of Racah parameter from its the free ion value of $971 \mathrm{~cm}^{-1}$ to 830 $\mathrm{cm}^{-1}$ and the $\beta^{0}$ value of $15 \%$. (Table-2).

Table-2: IR, Reflectance Spectral Data $\left(\mathrm{cm}^{-1}\right)$ and Magnetic Moments of Coordination Compounds of I

\begin{tabular}{|c|c|c|c|c|c|c|c|c|}
\hline Compound & $v_{\mathrm{as}}(\mathrm{COO})$ & $v_{\mathrm{s}}(\mathrm{COO})$ & $\begin{array}{c}v(\mathrm{C}-\mathrm{O}) \\
\text { (phenolic) }\end{array}$ & $\begin{array}{c}v(\mathrm{C}-\mathrm{N}) \\
(\beta \text {-lactam })\end{array}$ & $\begin{array}{l}v(\mathrm{C}-\mathrm{O}) \\
\text { (enolic) }\end{array}$ & $\begin{array}{c}v(\mathrm{C}-\mathrm{O}) \\
(\mathrm{MeOH})\end{array}$ & $v_{\max }$ & $\begin{array}{l}\text { Mag. } \\
\text { Moment } \\
\text { (B. M.) }\end{array}$ \\
\hline $\mathrm{LH}_{3}(\mathrm{I})$ & - & - & 1540 & 1414 & - & - & - & Diamagnetic \\
\hline $\begin{array}{c}{[\mathrm{Co}(\mathrm{LH})(\mathrm{Me}} \\
\mathrm{OH})]_{2}\end{array}$ & 1548 & 1342 & 1560 & 1385 & 1255 & 976 & $\begin{array}{l}8930, \\
13200, \\
20200\end{array}$ & 4.76 \\
\hline$[\mathrm{Ni}(\mathrm{LH})]$ & 1535 & 1330 & 1550 & 1370 & - & - & - & Diamagnetic \\
\hline
\end{tabular}

\section{Magnetic Measurements}

The magnetic moments of $[\mathrm{Co}(\mathrm{LH})(\mathrm{MeOH})]_{2}$ is $4.76 \mathrm{~B} . \mathrm{M}$ supporting its octahedral geometry. ${ }^{27}[\mathrm{Ni}(\mathrm{LH})]$ is diamagnetic.

Based on analytical data, molecular weight, valence requirements, spectral and magnetic studies, it is proposed that I behaves as a dibasic tetradentate OONO donor ligand in the monomeric, diamagnetic, fourcoordinate, square-planar compound [Ni(LH)] (III) and dimeric, six-coordinate, high-spin octahedral compound $[\mathrm{Co}(\mathrm{LH})(\mathrm{MeOH})]_{2}$ (II) (Fig.-1).

\section{Antibacterial Studies}

The antibacterial activity of ligand (I) and its complexes were tested against bacteria, E.Coli (Gramnegative) and $S$. aureus (Gram-positive) by using disc diffusion method (Table-3). The entire procedure and results are following our published paper. ${ }^{28}$

\section{Determination of Minimum Inhibitory Concentration (MIC)}

The entire procedure of determination of MIC (Table-4) and the results are in accordance with our published paper. ${ }^{15}$

Table-3: Antibacterial Activity of I and its Coordination Compounds (Zone of Inhibition in mm)

\begin{tabular}{c|c|c}
\hline Compound & $\begin{array}{c}\text { E.Coli } \\
\text { (Gram negative) }\end{array}$ & $\begin{array}{c}\text { S. Aureus } \\
\text { (Gram positive) }\end{array}$ \\
\hline $\mathrm{LH}_{3}(\mathrm{I})$ & 7 & 6 \\
\hline$[\mathrm{Co}(\mathrm{LH})(\mathrm{MeOH})]_{2}$ & 7 & 8 \\
\hline$[\mathrm{Ni}(\mathrm{LH})]$ & 7 & 10 \\
\hline
\end{tabular}


RASĀYAN J. Chem.

Vol. 13 | No. 4 |2538-2543| October - December | 2020

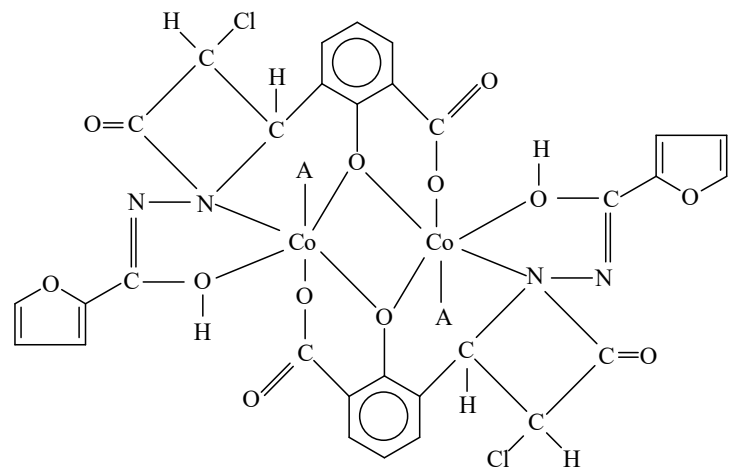

[II, $\mathrm{A}=\mathrm{MeOH}]$

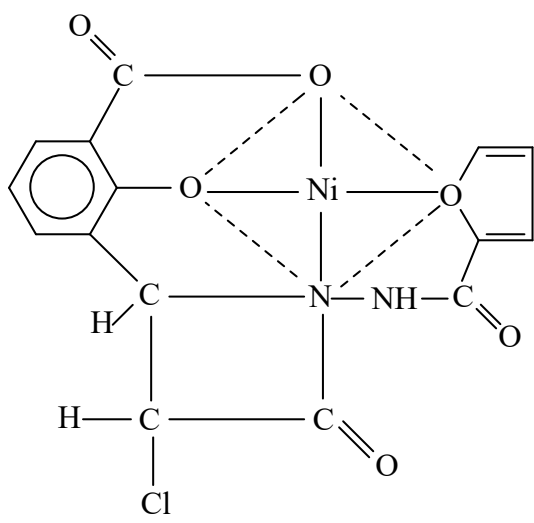

[III]

Fig.-1

Table-4: Minimum Inhibitory Concentration (MIC) of I and its Coordination Compounds $((\mu \mathrm{g} / \mathrm{ml})$

\begin{tabular}{c|c|c}
\hline Compound & $\begin{array}{c}\text { E. Coli } \\
\text { (Gram negative) }\end{array}$ & $\begin{array}{c}\text { S. Aureus } \\
\text { (Gram positive) }\end{array}$ \\
\hline $\mathrm{LH}_{3}(\mathrm{I})$ & 32 & 32 \\
\hline$[\mathrm{Co}(\mathrm{LH})(\mathrm{MeOH})]_{2}$ & 32 & 64 \\
\hline$[\mathrm{Ni}(\mathrm{LH})]$ & 64 & 64 \\
\hline
\end{tabular}

\section{CONCLUSION}

The elemental analyses, IR, reflectance and magnetic susceptibility measurements suggest an octahedral structure for $[\mathrm{Co}(\mathrm{LH})(\mathrm{MeOH})]_{2}$ (II) and a square-planar structure for $[\mathrm{Ni}(\mathrm{LH})]$ (III). Both the complexes shows antibacterial activities while testing with E.Coli (Gram Negative) and S. Aureus (Gram-positive) bacteria.

\section{REFERENCES}

1. P. Samadhiya, R. Sharma, S.K. Srivastava and S.D. Srivastava, Journal of Serbian Chemical Society, 77, 599 (2012), DOI:10.2298/JSC110616002S.

2. K. Govindarao N. Srinivasan and R. Suresh, Research Journal of Pharmacy and Technology, 13, 168 (2020), DOI:10.5958/0974-360X.2020.00034.7

3. C. Kabilan, D. Shankar, V. Alagarsamy and A. Asiya Parvin, Research Journal of Pharmaceutical, Biological and Chemical Sciences, 4, 1770 (2013).

4. S. Marupati, L. Eppakayala, S.Nuguri, R. Malothu and R. Merugu, 10, 1094 (2017).

5. H.S. Shailesh and S. P. Pankaj, Research Journal of Chemical Sciences, 2, 62 (2012).

6. D.K. Swamy, T.M. Bhagat, S.G. Badne and M.V. Dshmukh, Rasayan Journal of Chemistry, 3, 721 (2010).

7. H.L. Sharma, Principle of Pharmacology, 2, 748 (2008).

8. Y. Rokade and N. Dongare, Rasayan Journal of Chemistry, 3, 641 (2010).

9. B.S. Vashi, D.S. Mehta and V.H. Shah, Indian Journal of Chemistry, 34B, 802 (1995).

10. A.B. Duane, Current Medicinal Chemistry, 11, 1873(2004).

11. D. Kumar and A. Kumar, E-Journal of Chemistry, 9, 2532 (2012), DOI:10.1155/2012/147826

12. F.G. Mann and B.C. Saunders, Practical Organic Chemistry, London: Longmans,435(1961).

13. R.L. Dutta and A. Syamal, Elements of Magnetochemistry, $2^{\text {nd }}$ Edn., New Delhi: Affili-ated East West Press Pvt. Ltd. (1993)

14. D. Kumar, P.K. Gupta and A. Syamal, Indian Journal of Chemistry, 41 A, 2494 (2002).

15. D. Kumar and A. Kumar, Journal of Chemistry, Vol. 2014, Article ID 124790, 1 (2014), DOI: $10.1155 / 2014 / 124790$ 
RASĀYAN J. Chem.

Vol. 13 | No. 4 |2538-2543| October - December | 2020

16. E. Jayachandran, L.V.G. Nargund, A. Roy, G.M. Sreenivasa and K. Krupanidhi, Oriental Journal of Chemistry, 23, 829(2007).

17. D. Kumar and A. Kumar, Journal of Chemistry, Vol. 2014, Article ID 286136, 1(2014), DOI: $10.1155 / 2014 / 286136$

18. D. Kumar and A. Kumar, Chemistry: Bulgarian Journal of Science Education, 28, 505(2019).

19. Z.H. Chohan, C.T. Supuran and A. Scozzafava, Journal of Enzyme Inhibition and Medicinal Chemistry, 19, 79(2004), DOI:10.1080/14756360310001624939

20. B.D. Naik and K.R. Desai, Asian Journal of Chemistry, 16, 1749(2004).

21. A. Kumar, D. Kumar, P.K. Gupta and D. Dass, Rasayan Journal of Chemistry, 12, 577(2019), DOI: 10.31788/RJC.2019.1225081

22. P.K. Gupta, D. Kumar and A. Kumar, Asian Journal of Chemistry, 31, 2087(2019), DOI: 10.14233 /ajchem.2019.22142

23. D. Kumar, A. Kumar and D. Dass, Bulletin of Chemical Society of Ethiopia, 28, 29(2014), DOI: $10.4314 /$ bcse.v28i1.4

24. J. R. Ferraro, Low Frequency Vibrations of Inorganic and Coordination Compounds, Plenum Press, New York, 1971

25. A.B.P. Lever, Inorganic Electronic Spectroscopy, $2^{\text {nd }}$ Edn., Amsterdam: Elsevier, 1984 and references therein.

26. D. Kumar, A. Kumar, D. Dass and P.K. Gupta, Rasayan Journal of Chemistry, 8, 465 (2015).

27. F.A. Cotton, G. Wilkinson, C. Murillo, M. Bochmann, Advanced Inorganic Chemistry, $6^{\text {th }}$ edn., John Wiley, New York, 1999

28. D. Kumar, A. Kumar and D. Dass, Bulgarian Chemical Communications, 46, 238 (2014).

[RJC-5695/2020] 